\title{
Cerebellar location may predict an unfavourable prognosis in paediatric high-grade glioma
}

M Karremann ${ }^{*}, 1$, U Rausche ${ }^{2}$, D Roth ${ }^{2}$, A Kühn $^{2}$, T Pietsch $^{3}$, G H Gielen ${ }^{3}$, M Warmuth-Metz ${ }^{4}$, R-D Kortmann ${ }^{5}$, R Straeter ${ }^{6}$, A Gnekow $^{7}$, J E A Wolff ${ }^{8}$ and C M Kramm ${ }^{2,9}$

${ }^{1}$ Department of Paediatric and Adolescent Medicine, Universitätsmedizin Mannheim, Medical Faculty Mannheim, Heidelberg University, Theodor-Kutzer-Ufer 1-3, 68167 Mannheim, Germany; ${ }^{2}$ University Children's Hospital, 06120 Halle, Germany; ${ }^{3}$ Department of Neuropathology, 53105 Bonn, Germany; ${ }^{4}$ Department of Neuroradiology, University Hospital Wuerzburg, 97080 Wuerzburg, Germany; ${ }^{5}$ Department of Radiotherapy, University Hospital Leipzig, 04103 Leipzig, Germany; ${ }^{6}$ University Children's Hospital, 48149 Muenster, Germany; ${ }^{7}$ Children's Hospital, 86156 Augsburg, Germany; ${ }^{8}$ Floating Hospital for Children, Tufts University Medical Center, Boston, MA, USA and ${ }^{9}$ Department of Paediatrics I with Focus on Haematology and Oncology, University Medical Center Göttingen, 37099 Göttingen, Germany

Background: High-grade glioma (HGG) of the cerebellum accounts for only $5 \%$ of paediatric HGG. Since little is known about these tumours, the present study aimed at their further characterisation.

Methods: Twenty-nine paediatric patients with centrally reviewed cerebellar HGG were identified from the HIT-GBM/HIT-HGG database. Clinical and epidemiological data were compared with those of 180 paediatric patients with cortical HGG.

Results: Patients with cerebellar tumours were younger (median age of 7.6 vs 11.7 years, $P=0.028$ ), but both groups did not differ significantly with regard to gender, tumour predisposing syndromes, secondary HGG, primary metastasis, tumour grading, extent of tumour resection, chemotherapy regimen, or radiotherapy. Except for an increased incidence of anaplastic pilocytic astrocytoma (APA) in the cerebellar subset $(20.7 \%$ vs $3.3 \% ; P<0.001)$, histological entities were similarly distributed in both groups. As expected, tumour grading had a prognostic relevance on survival. Compared with cortical HGG, overall survival in the cerebellar location was significantly worse (median overall survival: $0.92 \pm 0.02$ vs $2.03 \pm 0.32$ years; $P=0.0064$ ), and tumour location in the cerebellum had an independent poor prognostic significance as shown by Cox-regression analysis $(P=0.019)$.

Conclusion: High-grade glioma represents a group of tumours with an obviously site-specific heterogeneity associated with a worse survival in cerebellar location.

Although brain tumours frequently arise in the posterior fossa beyond the first year of life (Pollack, 1999), only 5\% of all HGGs arise in the cerebellum, accounting for $<1 \%$ of all paediatric brain tumours (Kramm et al, 2008). Since previously published series are small or mixed up with adult patients (Chamberlain et al, 1990; Hayostek et al, 1993; Djalilian and Hall, 1998; Grahovac et al, 2009), merely little is known about paediatric HGG in this specific site.
The present study with 29 centrally reviewed paediatric HGG cases of the cerebellum aimed at a further characterisation of cerebellar HGG in children and adolescents with special emphasis on clinical characteristics and potential prognostic factors. Furthermore, we asked if these tumours may represent a clinically distinct subset of paediatric HGG. To investigate this hypothesis, paediatric patients with cerebellar HGG were compared with a control group of 180 paediatric patients with non-thalamic

*Correspondence: Dr M Karremann; E-mail michael.karremann@umm.de

Received 15 April 2013; revised 26 June 2013; accepted 27 June 2013; published online 18 July 2013

(c) 2013 Cancer Research UK. All rights reserved 0007-0920/13 
supratentorial HGG which had developed in cortical structures. This control group was chosen because both cerebellar and cerebral cortical tumours represent tumour populations with a supposedly facilitated surgical access, and extent of tumour resection still represents a strong prognostic parameter in paediatric HGG (Kramm et al, 2006). Results were critically reviewed in the light of the present literature.

\section{PATIENTS AND METHODS}

Patients' characteristics and inclusion/exclusion criteria. Patient data were obtained from the HIT-GBM/HIT-HGG database of the Society of Paediatric Oncology and Haematology in Germany, Austria, and Switzerland (Gesellschaft für Paediatrische Onkologie und Haematologie, GPOH). The HIT-GBM/HIT-HGG database contains clinical data of all patients enrolled in the various HIT-GBM/HIT-HGG trials since 1994 (Wolff et al, 2000, 2006, $2010 \mathrm{a}, \mathrm{b})$. For the present study, the following inclusion criteria were defined:

(A) Histopathological diagnosis of an HGG as defined by the WHO classification of central nervous system tumours (Louis et al, 2007) confirmed by central neuropathological review (The German Brain Tumour Reference Center, Department of Neuropathology, Bonn, Germany). High-grade gliomas included glioblastoma multiforme (GBM) WHO IV (M9440/3), anaplastic astrocytoma WHO III (M9401/3), anaplastic oligodendroglioma WHO III (M9451/3), anaplastic oligoastrocytoma WHO III (M9382/3; synonym: anaplastic mixed glioma WHO III), APA WHO III (M9421/3), anaplastic ganglioglioma WHO III (M9505/3), pleomorphic xanthoastrocytoma with signs of anaplasia (M9424/3), giant cell glioblastoma WHO IV (M9441/3), and glioblastoma with sarcomatous components WHO IV (M9442/3; gliosarcoma WHO IV).

(B) Patient age $0-17$ years at the time of initial diagnosis.

(C) Primary location within the cerebellum or cerebral cortex. Tumours that could not be accurately defined as primarily cerebellar or cortical were excluded.

By applying these criteria, 209 paediatric patients were identified: 29 with cerebellar HGG and 180 with HGG affecting the cortex (in the following, the term 'cortical HGG' will be used for this HGG subgroup). Informed consent for data storage and statistical analyses had been given by all patients and/or their parents at the time of enrolment in the various HIT-GBM/HITHGG trials in accordance to the Declaration of Helsinki.

HIT-GBM/HIT-HGG treatment protocols. Eligible paediatric patients older than 3 years but younger than 18 years with HGG and/or diffuse intrinsic pontine glioma had been enrolled in the various HIT-GBM/HIT-HGG trials since 1994. In all these trials, best feasible tumour resection was recommended before starting chemo- and/or radiotherapy. Standard fractionated radiotherapy (59.4 Gy total dose; daily fractions of $1.8 \mathrm{~Gy}$ over 6-7 weeks) was also common for all trials. In HIT-GBM-A, oral etoposide and trofosfamide were given during radiotherapy and continued for 1 more year after radiotherapy (Wolff et al, 2000). In HIT-GBM-B, cisplatinum, etoposide, and ifosfamide were given in two cycles concomitantly to radiotherapy followed by intravenous low-dose cyclophosphamide and subcutaneous interferon-gamma (Wolff et al, 2006). In HIT-GBM-C, weekly vincristine injections were added to the concomitant HIT-GBM-B radiochemotherapy. Chemotherapy with cisplatinum, etoposide, ifosfamide, and vincristine was continued during maintenance treatment (Wolff et al, 2010a). The concomitant radiochemotherapy of HIT-GBM-C was also adopted for HIT-GBM-D followed by a maintenance therapy with prednisolone, vincristine, and lomustine (CCNU). The therapeutic efficiency of two courses of high-dose methotrexate before radiotherapy was studied for feasibility in a pilot study (HIT-GBM pilot D) (Wolff et al, 2011) and then as a randomised question in HIT-GBM-D. Children younger than 3 years of age were primarily treated with surgery and chemotherapy alone following the HIT-SKK chemotherapy recommendation for infant patients with brain tumours (Rutkowski et al, 2005). Central neuropathological and central neuroradiological reviews were highly recommended in HIT-GBM-A and HIT-GBM-B and became mandatory for the HIT-GBM-C and HIT-GBM-D trials. The extent of tumour resection was determined on the basis of early post surgical imaging and/or the neurosurgical report. Gross-total tumour resection was defined as $100 \%$ macroscopic removal of the tumour mass. Subtotal tumour resection was defined as removal of $<100 \%$ but $\geqslant 90 \%$ of the tumour mass, partial tumour resection as $<90 \%$ resection. Biopsies were either performed as an open or stereotactic biopsy without tumour debulking.

Molecular biologic characterisation. TP53 accumulation was studied in 49 patients by immunohistochemistry using standard techniques, and H3.3 mutation analysis was performed in 6 cerebellar HGG by pyrosequencing as previously described (Gessi et al, 2013).

Statistical analysis. Statistical analysis was retrospectively performed using the statistical package for social studies (SPSS Inc, San Francisco, CA, USA). Overall (OS) and event-free survival (EFS) were determined by Kaplan-Meier analysis and log-rank testing. An event was defined as tumour relapse or progression, occurrence of a secondary malignancy, or death from any cause.

Statistical analysis of cerebellar and cortical HGGs was defined by the following parameters: histological tumour grading (WHO grade III/WHO grade IV), gender (male/female), median age ( $\leqslant 7$ years/ $>7$ years, only cerebellar subset) and extent of tumour resection (gross-total resection and no gross-total resection). The prognostic relevance regarding EFS and OS in cerebellar HGG was compared for the subgroups 'age', 'grading', 'gender', and 'extent of tumour resection' as defined above by Kaplan-Meier analysis and for both cortical and cerebellar HGGs by multivariate Coxregression analysis for the same subgroups. The relevance of tumour location (cerebellar $v s$ cortical) on OS and EFS was elucidated by both univariate Kaplan-Meier and multivariate Coxregression analysis for both the total group and a subset of patients with GBM. To compare the epidemiological distribution of disease/ treatment characteristics between the two HGG sites, the two-sided $\chi^{2}$-test was performed to determine significant differences regarding gender, distribution of grade III and IV tumours, histological diagnosis, secondary HGG, tumour predisposing syndromes, primary metastases, secondary metastasis, extent of tumour resection (total resection/subtotal resection/partial resection/biopsy and no resection), radiotherapy, chemotherapy regimen, and early response assessment (usually after radiotherapy or first SKK cycle around week 8 with the exception of the methotrexate group of HIT-GBM-D patients who were analysed at week 10), and accumulation of TP53. The difference of age distribution was evaluated by an unpaired, two-sided $t$-test. For all statistical analyses, the significance level was set at $P<0.05$.

\section{RESULTS}

Clinical and histological parameters as well as treatment characteristics of paediatric HGG of the cerebellum and the cerebral cortex are listed in Table 1. It appeared that cerebellar and cortical HGGs display many similar clinical characteristics. Sex ratio as well as incidence rates of secondary HGG, primary metastases, secondary metastases, and tumour predisposing 
Table 1. Clinical and treatment characteristics of paediatric HGG of the HIT-GBM/HIT-HGG database located in the cerebral cortex or the cerebellum

\begin{tabular}{|c|c|c|c|}
\hline & Cerebellar HGG & Cortical HGG & \\
\hline Total number & 29 & 180 & \\
\hline Age at diagnosis & & & $P=0.028^{a}$ \\
\hline $\begin{array}{l}\text { Median (years) } \\
\text { Mean (years) } \\
\text { Range (years) }\end{array}$ & $\begin{array}{c}7.6 \\
8.3 \\
0.8-16.9\end{array}$ & $\begin{array}{c}11.7 \\
10.5 \\
0-17.9\end{array}$ & \\
\hline Gender & & & $N S^{b}$ \\
\hline $\begin{array}{l}\text { Female } \\
\text { Male }\end{array}$ & $\begin{array}{l}10(34.5 \%) \\
19(65.5 \%)\end{array}$ & $\begin{array}{r}76(42.2 \%) \\
104(57.8 \%)\end{array}$ & \\
\hline Histological tumour grading & & & $N S^{b}$ \\
\hline $\begin{array}{l}\text { WHO III } \\
\text { WHO IV }\end{array}$ & $\begin{array}{l}10(34.5 \%) \\
19(65.5 \%)\end{array}$ & $\begin{array}{r}66(36.7 \%) \\
114(63.3 \%)\end{array}$ & \\
\hline \multicolumn{4}{|l|}{ Histological diagnosis } \\
\hline $\begin{array}{l}\text { Anaplastic pilocytic astrocytoma } \\
\text { Anaplastic astrocytoma } \\
\text { Anaplastic ganglioglioma } \\
\text { Glioblastoma multiforme } \\
\text { Gliosarcoma } \\
\text { Giant cell glioblastoma } \\
\text { Anaplastic oligoastrocytoma } \\
\text { Anaplastic oligodendroglioma } \\
\text { Pleomorphic xanthoastrocytoma with anaplasia }\end{array}$ & $\begin{array}{c}6(20.7 \%) \\
4(13.8 \%) \\
0 \\
17(53.3 \%) \\
0 \\
2(6.9 \%) \\
0 \\
0 \\
0\end{array}$ & $\begin{aligned} & 6(3.3 \%) \\
& 43(23.9 \%) \\
& 5(2.8 \%) \\
& 96(58.6 \%) \\
& 4(2.2 \%) \\
& 14(7.8 \%) \\
& 6(3.3 \%) \\
& 2(1.1 \%) \\
& 4(2.2 \%)\end{aligned}$ & $\begin{array}{c}P<0.001^{\mathrm{b}} \\
\mathrm{NS} \\
- \\
\mathrm{N} S^{\mathrm{b}} \\
- \\
\mathrm{NS}^{\mathrm{b}} \\
- \\
- \\
-\end{array}$ \\
\hline H3.3 mutation & & & - \\
\hline $\begin{array}{l}\text { Yes } \\
\text { No } \\
\text { Unknownc }\end{array}$ & $\begin{array}{c}0 \\
6(100 \%) \\
23(79 \%)\end{array}$ & $\begin{array}{c}- \\
- \\
180(100 \%)\end{array}$ & \\
\hline TP53 mutation & & & $N S^{b}$ \\
\hline $\begin{array}{l}\text { Yes } \\
\text { No } \\
\text { Unknownc }\end{array}$ & $\begin{array}{r}4(57 \%) \\
3(43 \%) \\
22(76 \%)\end{array}$ & $\begin{array}{r}22(52 \%) \\
20(48 \%) \\
138(77 \%)\end{array}$ & \\
\hline Secondary high-grade glioma & & & $N S^{b}$ \\
\hline $\begin{array}{l}\text { Yes } \\
\text { No } \\
\text { Unknown }\end{array}$ & $\begin{aligned} 1 & (3.6 \%) \\
27 & (96.4 \%) \\
1 & (3.4 \%)\end{aligned}$ & $\begin{array}{c}13(4.1 \%) \\
151(95.9 \%) \\
16(8.9 \%)\end{array}$ & \\
\hline Tumour predisposition syndromes & & & $N S^{b}$ \\
\hline $\begin{array}{l}\text { Yes } \\
\text { No } \\
\text { Unknownc }\end{array}$ & $\begin{array}{c}2 \text { (6.9\%) } \\
27 \text { (93.1\%) }\end{array}$ & $\begin{array}{c}7(4.1 \%) \\
164(95.2 \%) \\
9(4.0 \%)\end{array}$ & \\
\hline Primary metastasis & & & $N S^{b}$ \\
\hline $\begin{array}{l}\text { Yes } \\
\text { No } \\
\text { Unknown }\end{array}$ & $\begin{array}{r}4(13.8 \%) \\
25(86.2 \%)\end{array}$ & $\begin{array}{c}11(7.0 \%) \\
158(93.0 \%) \\
11(6.1 \%)\end{array}$ & \\
\hline Secondary metastasis & & & $N S^{b}$ \\
\hline $\begin{array}{l}\text { Yes } \\
\text { No } \\
\text { Unknownc }\end{array}$ & $\begin{array}{r}8(38.1 \%) \\
13(61.9 \%) \\
8(27.6 \%)\end{array}$ & $\begin{array}{l}37(30.3 \%) \\
85(69.7 \%) \\
58(31 \%)\end{array}$ & \\
\hline Extent of surgical resection & & & $N S^{b}$ \\
\hline $\begin{array}{l}\text { Gross-total tumour resection } \\
\text { Subtotal tumour resection } \\
\text { Partial tumour resection } \\
\text { Biopsy/no tumour surgery } \\
\text { Unknown }{ }^{c}\end{array}$ & $\begin{array}{r}9(31.0 \%) \\
12(41.4 \%) \\
5(17.2 \%) \\
3(10.3 \%)\end{array}$ & $\begin{array}{c}70(39.1 \%) \\
37(20.7 \%) \\
45(25.1 \%) \\
27(15.1 \%) \\
1(0.6 \%)\end{array}$ & $\begin{aligned} & P= 0.014^{\mathrm{b}} \\
& \text { NS } \\
& \text { NS }\end{aligned}$ \\
\hline Radiotherapy & & & $N S^{b}$ \\
\hline $\begin{array}{l}\text { Yes } \\
\text { No } \\
\text { Unknownc }\end{array}$ & $\begin{aligned} 24 & (85.7 \%) \\
4 & (14.3 \%) \\
1 & (3.4 \%)\end{aligned}$ & $\begin{array}{c}149(88.7 \%) \\
19(11.3 \%) \\
12(6.7 \%)\end{array}$ & \\
\hline
\end{tabular}


Table 1. (Continued)

\begin{tabular}{|c|c|c|c|}
\hline & Cerebellar HGG & Cortical HGG & \\
\hline Chemotherapy & & & - \\
\hline $\begin{array}{l}\text { No } \\
\text { HIT-GBM-A } \\
\text { HIT-GBM-B } \\
\text { HIT-GBM-C } \\
\text { HIT-GBM-D } \\
\text { HIT-SKK } \\
\text { Other chemotherapy } \\
\text { Unknownc }\end{array}$ & $\begin{array}{c}0 \\
1(3.4 \%) \\
3(10.3 \%) \\
6(20.7 \%) \\
12(41.4 \%) \\
5(17.2 \%) \\
2(6.9 \%)\end{array}$ & $\begin{array}{l}11(6.3 \%) \\
11(6.3 \%) \\
13(7.5 \%) \\
36(20.7 \%) \\
70(40.2 \%) \\
17(9.8 \%) \\
19(10.9 \%) \\
6(3.3 \%)\end{array}$ & \\
\hline Early response & & & NS \\
\hline $\begin{array}{l}\text { Overall complete response } \\
\text { Complete response/Continuing complete response } \\
\text { Partial response } \\
\text { Stable disease } \\
\text { Progressive disease } \\
\text { Unknown }\end{array}$ & $\begin{aligned} 10 & (41.6 \%) \\
2 / 8 & (8.3 \% / 33.3 \%) \\
& 2(8.3 \%) \\
& 4(16.7 \%) \\
& 8(33.3 \%) \\
& 5(17.2 \%)\end{aligned}$ & $\begin{array}{c}57(38.5 \%) \\
18 / 39(12.2 \% / 26.4 \%) \\
18(12.2 \%) \\
40(27.0 \%) \\
33(22.3 \%) \\
32(17.8 \%)\end{array}$ & \\
\hline Relapse therapy & & & - \\
\hline $\begin{array}{l}\text { Chemotherapy } \\
\text { Surgery } \\
\text { Radiotherapy } \\
\text { None } \\
\text { Unknownc } \\
\end{array}$ & $\begin{aligned} & 10(63 \%) \\
& 1(6 \%) \\
& 2(13 \%) \\
& 3(19 \%) \\
& 13(45 \%) \\
&\end{aligned}$ & $\begin{aligned} 59 & (78 \%) \\
3 & (4 \%) \\
1 & (1 \%) \\
13 & (17 \%) \\
104 & (58 \%)\end{aligned}$ & \\
\hline \multicolumn{4}{|c|}{ 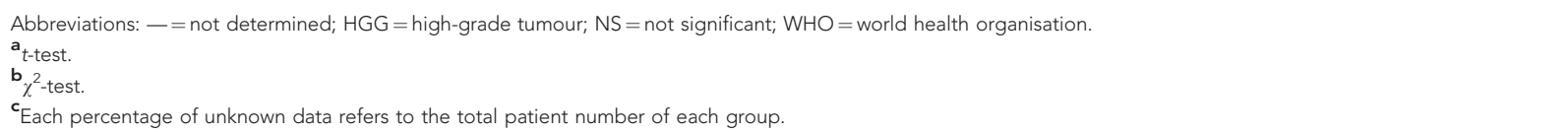 } \\
\hline
\end{tabular}

syndromes did not differ significantly between both tumour sites. However, patients with cerebellar HGG were significantly younger than patients with cortical HGG (median age 7.6 vs 11.7 years, $P=0.028$ ). The histological entities were found in both sites with a similar distribution except for APAs WHO grade III that were significantly associated with a cerebellar location. The frequency of WHO grade III and IV gliomas in cortex and cerebellum was also similar. In addition, few tumours were characterised for H3.3 mutation and TP53 accumulation. TP53 status did not differ significantly between both sides. Noteworthily, no H3.3 mutation was found in six cerebellar tumours.

No significant difference was found regarding therapy: while frequency of gross-total tumour resection seemed to be increased in cortical HGG (39.1\% vs 31.0\%), in cerebellar HGG subtotal resection was more frequent (41.4\% vs $20.7 \%)$. Hence, in $72.4 \%$ of cerebellar HGG and $59.8 \%$ of cortical HGG at least $90 \%$ tumour resection could be achieved (not significant). Most patients received radiotherapy, while 11 patients with cortical HGG did not receive any chemotherapy, all patients with cerebellar HGG did. Distribution of chemotherapy regimen between both sites was comparable (Table 1). Regarding early response assessment after radiotherapy (weeks 8-10), both groups did not differ significantly, and complete remission (CR) was found in $41.6 \%$ of cerebellar HGG vs 38.5\% of cortical HGG.

In our cohort of 29 patients with cerebellar HGG, tumour grading (WHO grade III versus IV) was strongly associated with survival. Patients with WHO grade III tumours had a superior OS and EFS in comparison to patients with WHO grade IV tumours as shown by Kaplan-Meier estimate (Table 2) and multivariate Coxregression analysis (Table 3 ). There was no significant prognostic relevance of the extent of tumour resection on survival: gross-total tumour resection did not translate into a significantly improved OS or EFS in both univariate and multivariate analysis. In addition, in cerebellar HGG age ( $\leqslant 7$ vs $>7$ years) and gender were not significantly associated with survival as shown by Kaplan-Meier analysis and Cox-regression analysis (Tables 2 and 3).

Patients with HGG of the cerebellum exhibited a worse overall survival compared with cortical HGG. The median OS differed significantly by log-rank testing $(P=0.0064)$ and was $2.03 \pm 0.32 \mathrm{vs}$ $0.92 \pm 0.02$ years in cortical and cerebellar HGGs, respectively (Figure 1). One-year OS was $77 \pm 3 \%$ vs $41 \pm 9 \%$, 2-year OS $52 \pm 4 \%$ vs $33 \pm 9 \%$, and 5 -year OS $32 \pm 5 \%$ vs $16 \pm 9 \%$ for cortical and cerebellar HGGs, respectively. In contrary, median EFS was worse in cerebellar HGG but did not differ significantly: $0.91 \pm 0.09$ vs $0.62 \pm 0.17$ years in cortical and cerebellar HGGs, respectively. One-year EFS was $47 \pm 4 \%$ vs $34 \pm 9 \%$, 2-year EFS $30 \pm 4 \%$ vs $25 \pm 9 \%$, and 5 -year EFS $24 \pm 4 \%$ vs $8 \pm 7 \%$ for cortical and cerebellar HGGs, respectively. In addition, multivariate Coxregression analysis corroborated these findings and revealed an independent prognostic significance of tumour location for OS, but not for EFS (Table 3). These findings were also confirmed for the subset of patients with GBM including 96 and 17 patients with cortical and cerebellar diseases, respectively. Median OS was $1.53 \pm 0.23$ vs $0.9 \pm 0.03$ years $(P=0.0079)$ and median EFS was $0.66 \pm 0.13$ vs $0.53 \pm 0.17$ years (not significant) in cortical $v s$ cerebellar GBM. In multivariate Cox-regression analysis, location in the cerebellum was of independent prognostic significance for OS $(P=0.037$, Figure 2$)$ but not for EFS. Both subgroups did not differ significantly with respect to age, gender, incidence of primary and secondary metastasis, tumour predisposing syndromes as well as extent of tumour resection, application of radiotherapy, chemotherapy regimens and early treatment response after 8-10 weeks (data not shown). In this subgroup, some tumours were screened for biological characteristics: none of the four cerebellar GBM exhibited a H3.3 mutation. Concerning TP53 status, half of the tumours screened in each location exhibited an accumulation: 14 out of 28 cortical and 2 out of 4 cerebellar GBM, respectively. 
Table 2. OS and EFS of 29 paediatric patients with HGG from the German HIT-GBM/HIT-HGG database with cerebellar tumour

\begin{tabular}{|c|c|c|c|c|c|c|c|c|c|}
\hline & \multicolumn{5}{|c|}{ Event-free survival } & \multicolumn{4}{|c|}{ Overall survival } \\
\hline & Number & $\begin{array}{c}\text { One-year } \\
\text { EFS }\end{array}$ & $\begin{array}{l}\text { Two-year } \\
\text { EFS }\end{array}$ & $\begin{array}{c}\text { Five-year } \\
\text { EFS }\end{array}$ & Log rank & $\begin{array}{l}\text { One-year } \\
\text { OS }\end{array}$ & $\begin{array}{l}\text { Two-year } \\
\text { OS }\end{array}$ & $\begin{array}{l}\text { Five-year } \\
\text { OS }\end{array}$ & Log rank \\
\hline Gender & & & & & NS & & & & NS \\
\hline $\begin{array}{l}\text { Female } \\
\text { Male }\end{array}$ & $\begin{array}{l}n=10 \\
n=19\end{array}$ & $\begin{array}{l}20 \pm 12 \% \\
42 \pm 12 \%\end{array}$ & $\begin{array}{l}20 \pm 12 \% \\
28 \pm 12 \%\end{array}$ & $\begin{array}{c}0 \\
14 \pm 12 \%\end{array}$ & & $\begin{array}{l}30 \pm 14 \% \\
48 \pm 12 \%\end{array}$ & $\begin{array}{l}30 \pm 14 \% \\
29 \pm 11 \%\end{array}$ & $\begin{array}{l}15 \pm 13 \% \\
14 \pm 12 \%\end{array}$ & \\
\hline Age at diagnosis & & & & & NS & & & & NS \\
\hline $\begin{array}{l}\leqslant 7 \text { years } \\
>7 \text { years }\end{array}$ & $\begin{array}{l}n=16 \\
n=13\end{array}$ & $\begin{array}{l}39 \pm 13 \% \\
26 \pm 13 \%\end{array}$ & $\begin{array}{l}23 \pm 12 \% \\
26 \pm 13 \%\end{array}$ & $\begin{array}{c}12 \pm 10 \% \\
0\end{array}$ & & $\begin{array}{l}41 \pm 13 \% \\
42 \pm 14 \%\end{array}$ & $\begin{array}{l}41 \pm 13 \% \\
21 \pm 13 \%\end{array}$ & $\begin{array}{l}12 \pm 10 \% \\
21 \pm 13 \%\end{array}$ & \\
\hline Grading & & & & & $P=0.0202$ & & & & $P=0.0079$ \\
\hline $\begin{array}{l}\text { WHO III } \\
\text { WHO IV }\end{array}$ & $\begin{array}{l}n=10 \\
n=19\end{array}$ & $\begin{array}{l}68 \pm 16 \% \\
14 \pm 9 \%\end{array}$ & $\begin{array}{c}56 \pm 17 \% \\
7 \pm 6 \%\end{array}$ & $\begin{array}{c}19 \pm 16 \% \\
0\end{array}$ & & $\begin{array}{l}79 \pm 13 \% \\
22 \pm 10 \%\end{array}$ & $\begin{array}{l}66 \pm 16 \% \\
11 \pm 7 \%\end{array}$ & $\begin{array}{c}44 \pm 21 \% \\
6 \pm 5 \%\end{array}$ & \\
\hline Extent of tumour resection & & & & & NS & & & & NS \\
\hline $\begin{array}{l}\text { Gross total resection } \\
\text { No gross-total resection }\end{array}$ & $\begin{array}{c}n=9 \\
n=20\end{array}$ & $\begin{array}{l}52 \pm 18 \% \\
25 \pm 10 \% \\
\end{array}$ & $\begin{array}{l}39 \pm 17 \% \\
19 \pm 10 \% \\
\end{array}$ & $\begin{array}{c}0 \\
9 \pm 8 \% \\
\end{array}$ & & $\begin{array}{l}51 \pm 18 \% \\
37 \pm 11 \% \\
\end{array}$ & $\begin{array}{l}38 \pm 17 \% \\
25 \pm 10 \% \\
\end{array}$ & $\begin{array}{c}0 \\
17 \pm 10 \% \\
\end{array}$ & \\
\hline
\end{tabular}

Table 3. Cox-regression analysis of overall survival and event-free survival in our cohort of HGG affecting the cortex (180 patients) or the cerebellum (29 patients) for the subgroups 'gender', 'age', 'histological grading', and 'extent of tumour resection'

\begin{tabular}{|c|c|c|c|c|c|c|}
\hline & \multicolumn{2}{|c|}{ HGG of the cortex } & \multicolumn{2}{|c|}{ HGG of the cerebellum } & \multicolumn{2}{|c|}{ All HGG } \\
\hline & EFS & OS & EFS & OS & EFS & OS \\
\hline Gender & NS & NS & NS & NS & NS & NS \\
\hline Age & - & - & NS & NS & - & - \\
\hline Grading & $P<0.001$ & $P<0.001$ & $P=0.016$ & $P=0.012$ & $P<0.001$ & $P<0.001$ \\
\hline $\begin{array}{l}\text { Tumour } \\
\text { resection }\end{array}$ & $P<0.001$ & $P<0.001$ & NS & NS & $P<0.001$ & $P<0.001$ \\
\hline Tumour site & - & - & - & - & NS & $P=0.019$ \\
\hline
\end{tabular}

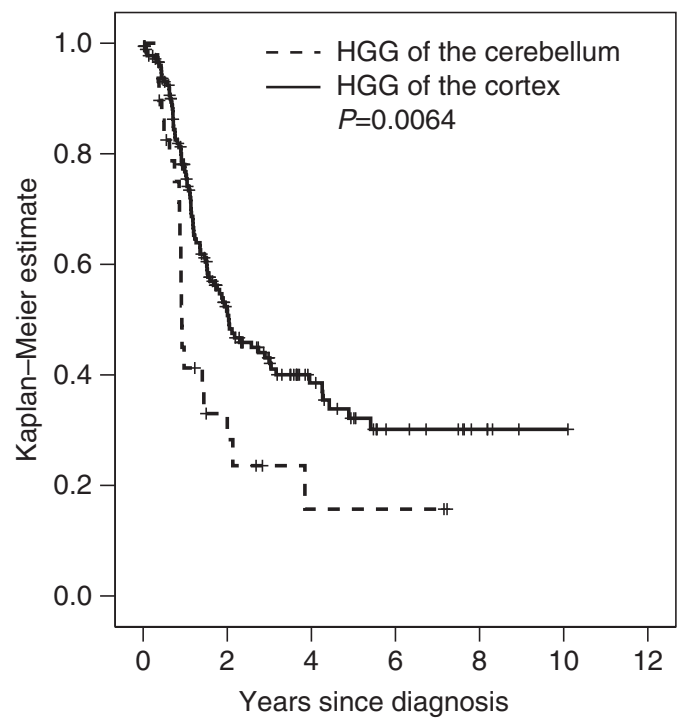

Figure 1. Kaplan-Meier analysis of overall survival in paediatric patients with high-grade glioma of the cerebral cortex $(n=180)$ and the cerebellum $(n=29)$.

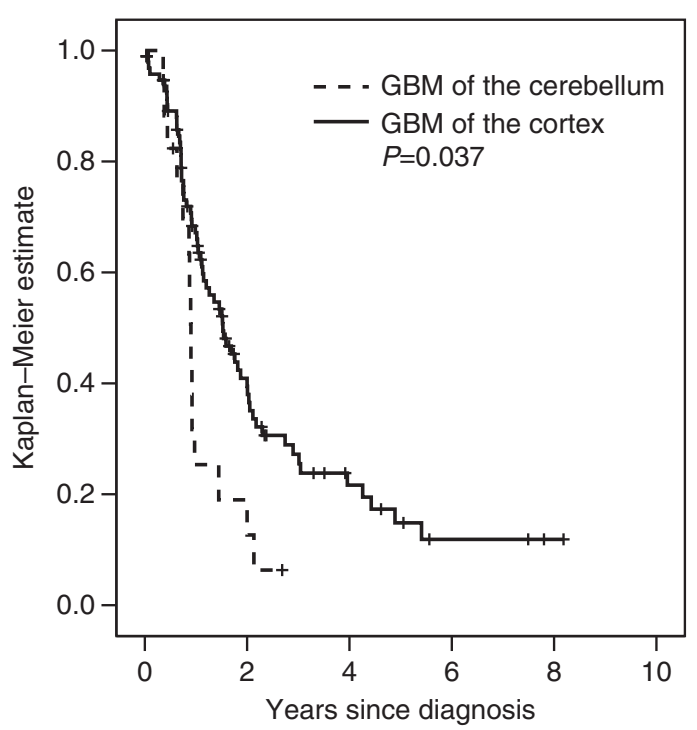

Figure 2. Kaplan-Meier analysis of overall survival in paediatric patients with GBM of the cerebral cortex $(n=96)$ and the cerebellum ( $n=17$ ). 


\section{DISCUSSION}

High-grade glioma in children represents a non-homogenous group of glial tumours characterised by WHO grade III or IV histology. They account for $10 \%$ of all paediatric brain tumours, but only 5\% of HGG arise in the cerebellum (Campbell et al, 1996; Kramm et al, 2008; Fangusaro, 2009). Since reports are rare and mainly studied adult patients (Chamberlain et al, 1990; Hayostek et al, 1993; Djalilian and Hall, 1998), only little is known about paediatric HGG in this specific site. Thus, the present study aimed at a further characterisation of paediatric cerebellar HGG and also investigated if $\mathrm{HGG}$ in this location may represent a distinct clinical subset in comparison with cortical HGG in paediatric patients.

Most epidemiologic characteristics were comparable between both sides and did not differ from previous reports mainly in adult patients including gender (Chamberlain et al, 1990; Hayostek et al, 1993), tumour predisposing syndroms (Fangusaro, 2009), incidence of primary metastasis (Benesch et al, 2005), and tumour grading. In line with previous reports, gender did not influence prognosis (Hayostek et al, 1993; Djalilian and Hall, 1998), while patients with WHO grade III tumours exhibited a superior OS and EFS compared with WHO grade IV tumours in cerebellar and cortical HGGs (Djalilian and Hall, 1998; Pollack, 1999; Fangusaro, 2009).

High-grade glioma usually affects children of all age groups with a median age of $\sim 9$ years (Fangusaro, 2009). This is younger than the median age of our cohort with cortical HGG and older than the median age of our patients with cerebellar HGG. Obviously, there seems to be some differences in median age at diagnosis between the different affected sites of paediatric HGG: 11.5 years for thalamic HGG (Kramm et al, 2011), 11.3 years for spinal HGG (Wolff et al, 2012), 11.7 years for cortical HGG (this study), 8.0 years for pontine gliomas (Kramm et al, 2011), and 7.6 years for cerebellar HGG (this study). Although not all of these differences are significant these observations may still reflect different subentities of paediatric HGG. Nevertheless, age (older and younger than median age) did not have a significant relevance on OS and EFS in our series of cerebellar HGG.

In our cohort, the histological entities were equally distributed over both sites except for an unexpected and unprecedented significantly increased incidence of APAs in the cerebellum. However, since APA was not introduced in the WHO classification of brain tumours until 2000, it cannot play the same role in previous paediatric series as published by Bertolone (patients enrolled between 1985 and 1990) (Bertolone et al, 2003). Therefore, further studies are necessary to confirm the high incidence of APA in children with cerebellar HGG, which might be explained by the fact that WHO grade I pilocytic astrocytomas are frequently found within the posterior fossa (Fernandez et al, 2003) and that WHO grade III APAs may follow the same pattern as their lowgrade counterparts. Some of the APAs might also have arisen from previous subclinical WHO grade I pilocytic astrocytoma within the cerebellum since such malignant transformation had been reported before (Fangusaro, 2009; Otero-Rodriguez et al, 2010; Peters et al, 2011). However, malignant transformation of a subclinical WHO grade I pilocytic astrocytoma still seems an extraordinary clinical rarity and is often associated with prior irradiation or chemotherapy.

In paediatric $\mathrm{HGG}$, the extent of tumour resection is a strong prognostic factor, and gross-total resection is associated with the best survival (Finlay et al, 1995; Campbell et al, 1996; Pollack, 1999; Kramm et al, 2006). Although gross-total tumour resection was significantly associated in cortical HGG with a superior OS and EFS, this finding could not be confirmed in the subset of patients with cerebellar HGG. This is in contrast to adult patients with cerebellar HGG who had benefitted from complete tumour resection (Djalilian and Hall, 1998) and might be due to the small patient numbers in our study. Therefore, we still recommend aiming for a gross-total tumour resection whenever possible until further data will support (or disprove) our present findings of the impact of gross-total tumour resection in paediatric cerebellar HGG.

In the last few years, there is an increasing evidence of a sitespecific genetic heterogeneity in paediatric HGG, for example, SETD2 mutations were restricted to the cerebral hemispheres in a series of 60 paediatric HGG (Fontebasso et al, 2013), p53 immunoreactivity was frequently found with supratentorial tumour but was absent in cerebellar tumours in a series of 54 paediatric GBM (Ganigi et al, 2005), and an amplification of 7q21-22 (including the CDK6 gene) was detected exclusively in supratentorial glioblastoma in a series of 18 children $(\mathrm{Qu}$ et al, 2010). To elucidate, whether this genetic heterogeneity of cerebellar and cortical HGGs may translate into a site-specific varying survival, the HIT-GBM/HIT-HGG database was screened for HGG of the cortex. Cerebellar and cortical HGGs shared most of the epidemiological characteristics except for an increased incidence of APA in the cerebellum (Table 1). The extent of tumour resection, frequency of radiotherapy, and chemotherapy regimen did not differ among both groups, and furthermore, early response assessment after radiotherapy (i.e., weeks 8-10) was comparable between both sites.

Despite all these parameters so similar between both sites, prognosis in cerebellar HGG was worse both for the entire cohort and for a subset of GBM. Overall survival was significantly impaired in cerebellar HGG as shown by Kaplan-Meier analysis, and in contrary to a series of adult patients (Djalilian and Hall, 1998), tumour location in the cerebellum was found to be an independent prognostic parameter of OS by multivariate Coxregression analysis. This finding was confusing regarding the increased incidence of APA in the cerebellum because survival in APA was favourable in previous reports (Tomlinson et al, 1994; Krieger et al, 1997). The present finding might be explained by a more effective salvage therapy in cortical tumours, because EFS did not differ significantly. However, there were numerous strategies that were similar in both groups (Table 1) and hence cannot explain the different survival.

Since the tumour site itself was identified as a prognostic parameter and any explanation for the observed clinical differences has probably to go beyond pure differences in neurosurgical accessibility in the different tumour localisations, a varying tumour biology may well explain clinical differences between the investigated tumour sites. In this regard, our previous findings, that clinical characteristics of paediatric HGG of the Thalamus do share more similarities with pontine HGG than with supratentorial HGG (Kramm et al, 2011), correlate well with the high frequency of H3F3A K27 mutations in thalamic and pontine gliomas published just recently (Khuong-Quang et al, 2012; Schwartzentruber et al, 2012; Sturm et al, 2012). In the present cohort, we could not show a different incidence of TP53 accumulation between cortical and cerebral HGGs. Noteworthily, no H3.3 mutations were documented in cerebellar HGG, so it is unlikely that a high incidence of the K27M H3.3 mutation might explain the poor prognosis of the cerebellar subset. However, these results must be assessed carefully and further studies are necessary, since the HIT-GBM/HIT-HGG database is clinically based, and unfortunately contains only fragmentary tumour biology data, so that in the present cohort, H3.3 and TP53 status was documented in less than one-fourth of patients.

In conclusion, the present study encompasses the largest series of paediatric cerebellar HGG to date. Only patients with central neuropathological review were analysed to ensure a high quality control level for the data presented here. Most surprisingly, 
gross-total tumour resection did not significantly improve survival in our cohort of cerebellar HGG which may be due to the low patient number with total tumour resection. In our series, cerebellar HGG shared most of the investigated epidemiological and treatment characteristics with HGG affecting the cortex. Despite these similarities, cerebellar HGG showed a significantly worse survival in comparison with cortical HGG, and tumour site appeared to represent an independent prognostic parameter. Future molecular analyses shall help to corroborate our observations of the obviously site-specific heterogeneity of paediatric HGG on a molecular genetic basis and further to elucidate the biology of cerebellar HGG in children.

\section{ACKNOWLEDGEMENTS}

The ongoing support of the Deutsche Kinderkrebsstiftung, Bonn, Germany, is greatly acknowledged. Without this support performance of clinical trials as well as quality control measures like central neuropathological and neuroradiological review and a central review of radiotherapy planning would not be possible within the German paediatric brain tumour (HIT) network. We also thank all colleagues who contributed patients and their data to the HIT-GBM/HIT-HGG studies. The present research is based on the clinical data from the HIT-GBM/HIT-HGG trials, which were all funded by the Deutsche Kinderkrebsstiftung, Bonn, Germany. The present investigation is part of the ongoing assessments of the HIT-GBM and HIT-HGG trials. All these trials and their evaluation were approved by ethical review boards of the participating centres. In addition, the present study complies with the current German law.

\section{CONFLICT OF INTEREST}

The authors declare no conflict of interest.

\section{REFERENCES}

Benesch M, Wagner S, Berthold F, Wolff JE (2005) Primary dissemination of high-grade gliomas in children: experiences from four studies of the Pediatric Oncology and Hematology Society of the German Language Group (GPOH). J Neurooncol 72(2): 179-183.

Bertolone SJ, Yates AJ, Boyett JM, Wallace D, Finlay JL (2003) Combined modality therapy for poorly differentiated gliomas of the posterior fossa in children: a Children's Cancer Group report. J Neurooncol 63(1): 49-54.

Campbell JW, Pollack IF, Martinez AJ, Shultz B (1996) High-grade astrocytomas in children: radiologically complete resection is associated with an excellent long-term prognosis. Neurosurgery 38(2): 258-264.

Chamberlain MC, Silver P, Levin VA (1990) Poorly differentiated gliomas of the cerebellum. A study of 18 patients. Cancer 65(2): 337-340.

Djalilian HR, Hall WA (1998) Malignant gliomas of the cerebellum: an analytic review. J Neurooncol 36(3): 247-257.

Fangusaro J (2009) Pediatric high-grade gliomas and diffuse intrinsic pontine gliomas. J Child Neurol 24(11): 1409-1417.

Fernandez C, Figarella-Branger D, Girard N, Bouvier-Labit C, Gouvernet J, Paz Paredes A, Lena G (2003) Pilocytic astrocytomas in children: prognostic factors-a retrospective study of 80 cases. Neurosurgery 53(3): 544-553, discussion 554-5.

Finlay JL, Boyett JM, Yates AJ, Wisoff JH, Milstein JM, Geyer JR, Bertolone SJ, McGuire P, Cherlow JM, Tefft M et al. (1995) Randomized phase III trial in childhood high-grade astrocytoma comparing vincristine, lomustine, and prednisone with the eight-drugs-in-1-day regimen. Childrens Cancer Group. J Clin Oncol 13(1): 112-123.

Fontebasso AM, Schwartzentruber J, Khuong-Quang DA, Liu XY, Sturm D, Korshunov A, Jones DT, Witt H, Kool M, Albrecht S, Fleming A, Hadjadj D, Busche S, Lepage P, Montpetit A, Staffa A, Gerges N,
Zakrzewska M, Zakrzewski K, Liberski PP, Hauser P, Garami M, Klekner A, Bognar L, Zadeh G, Faury D, Pfister SM, Jabado N, Majewski J (2013) Mutations in SETD2 and genes affecting histone H3K36 methylation target hemispheric high-grade gliomas. Acta Neuropathol 125(5): 659-669.

Ganigi PM, Santosh V, Anandh B, Chandramouli BA, Sastry Kolluri VR (2005) Expression of p53, EGFR, pRb and bcl-2 proteins in pediatric glioblastoma multiforme: a study of 54 patients. Pediatr Neurosurg 41(6): 292-299.

Gessi M, Gielen GH, Hammes J, Dorner E, Muhlen AZ, Waha A, Pietsch T (2013) H3.3 G34R mutations in pediatric primitive neuroectodermal tumors of central nervous system (CNS-PNET) and pediatric glioblastomas: possible diagnostic and therapeutic implications? J Neurooncol 112(1): 67-72.

Grahovac G, Tomac D, Lambasa S, Zoric A, Habek M (2009) Cerebellar glioblastomas: pathophysiology, clinical presentation and management. Acta Neurochir (Wien) 151(6): 653-657.

Hayostek CJ, Shaw EG, Scheithauer B, O'Fallon JR, Weiland TL, Schomberg PJ, Kelly PJ, Hu TC (1993) Astrocytomas of the cerebellum. A comparative clinicopathologic study of pilocytic and diffuse astrocytomas. Cancer 72(3): 856-869.

Khuong-Quang DA, Buczkowicz P, Rakopoulos P, Liu XY, Fontebasso AM, Bouffet E, Bartels U, Albrecht S, Schwartzentruber J, Letourneau L, Bourgey M, Bourque G, Montpetit A, Bourret G, Lepage P, Fleming A, Lichter P, Kool M, von Deimling A, Sturm D, Korshunov A, Faury D, Jones DT, Majewski J, Pfister SM, Jabado N, Hawkins C (2012) K27M mutation in histone H3.3 defines clinically and biologically distinct subgroups of pediatric diffuse intrinsic pontine gliomas. Acta Neuropathol 124(3): 439-447.

Kramm C, Rausche U, Butenhoff S, Kühnöl C, Kunze C, Kortmann R, Wolff JE, van Gool S (2008) Hochmaligne Gliome im Kindes- und Jugendalter. Monatsschr Kinderheilk 156(12): 1201-1207.

Kramm CM, Butenhoff S, Rausche U, Warmuth-Metz M, Kortmann RD, Pietsch T, Gnekow A, Jorch N, Janssen G, Berthold F, Wolff JE (2011) Thalamic high-grade gliomas in children: a distinct clinical subset? Neuro Oncol 13(6): 680-689.

Kramm CM, Wagner S, Van Gool S, Schmid H, Strater R, Gnekow A, Rutkowski S, Wolff JE (2006) Improved survival after gross total resection of malignant gliomas in pediatric patients from the HIT-GBM studies. Anticancer Res 26(5B): 3773-3779.

Krieger MD, Gonzalez-Gomez I, Levy ML, McComb JG (1997) Recurrence patterns and anaplastic change in a long-term study of pilocytic astrocytomas. Pediatr Neurosurg 27(1): 1-11.

Louis DN, Ohgaki H, Wiestler OD, Cavenee WK (2007) WHO Classification of Tumours of the Central Nervous System. 3rd edn. WHO Press: Lyon.

Otero-Rodriguez A, Sarabia-Herrero R, Garcia-Tejeiro M, Zamora-Martinez T (2010) Spontaneous malignant transformation of a supratentorial pilocytic astrocytoma. Neurocirugia (Astur) 21(3): 245-252.

Peters KB, Cummings TJ, Gururangan S (2011) Transformation of juvenile pilocytic astrocytoma to anaplastic pilocytic astrocytoma in patients with neurofibromatosis type I. J Pediatr Hematol Oncol 33(5): e198-e201.

Pollack IF (1999) Pediatric brain tumors. Semin Surg Oncol 16(2): 73-90.

Qu HQ, Jacob K, Fatet S, Ge B, Barnett D, Delattre O, Faury D, Montpetit A, Solomon L, Hauser P, Garami M, Bognar L, Hansely Z, Mio R, Farmer JP, Albrecht S, Polychronakos C, Hawkins C, Jabado N (2010) Genome-wide profiling using single-nucleotide polymorphism arrays identifies novel chromosomal imbalances in pediatric glioblastomas. Neuro Oncol 12(2): 153-163.

Rutkowski S, Bode U, Deinlein F, Ottensmeier H, Warmuth-Metz M, Soerensen N, Graf N, Emser A, Pietsch T, Wolff JE, Kortmann RD, Kuehl J (2005) Treatment of early childhood medulloblastoma by postoperative chemotherapy alone. $N$ Engl J Med 352(10): 978-986.

Schwartzentruber J, Korshunov A, Liu XY, Jones DT, Pfaff E, Jacob K, Sturm D, Fontebasso AM, Quang DA, Tonjes M, Hovestadt V, Albrecht S, Kool M, Nantel A, Konermann C, Lindroth A, Jager N, Rausch T, Ryzhova M, Korbel JO, Hielscher T, Hauser P, Garami M, Klekner A, Bognar L, Ebinger M, Schuhmann MU, Scheurlen W, Pekrun A, Fruhwald MC, Roggendorf W, Kramm C, Durken M, Atkinson J, Lepage P, Montpetit A, Zakrzewska M, Zakrzewski K, Liberski PP, Dong Z, Siegel P, Kulozik AE, Zapatka M, Guha A, Malkin D, Felsberg J, Reifenberger G, von Deimling A, Ichimura K, Collins VP, Witt H, Milde T, Witt O, Zhang C, Castelo-Branco P, Lichter P, Faury D, Tabori U, Plass C, Majewski J, Pfister SM, Jabado N 
(2012) Driver mutations in histone H3.3 and chromatin remodelling genes in paediatric glioblastoma. Nature 482(7384): 226-231.

Sturm D, Witt H, Hovestadt V, Khuong-Quang DA, Jones DT, Konermann C, Pfaff E, Tonjes M, Sill M, Bender S, Kool M, Zapatka M, Becker N, Zucknick M, Hielscher T, Liu XY, Fontebasso AM, Ryzhova M, Albrecht S, Jacob K, Wolter M, Ebinger M, Schuhmann MU, van Meter T, Fruhwald MC, Hauch H, Pekrun A, Radlwimmer B, Niehues T, von Komorowski G, Durken M, Kulozik AE, Madden J, Donson A, Foreman NK, Drissi R, Fouladi M, Scheurlen W, von Deimling A, Monoranu C, Roggendorf W, Herold-Mende C, Unterberg A, Kramm CM, Felsberg J, Hartmann C, Wiestler B, Wick W, Milde T, Witt O, Lindroth AM, Schwartzentruber J, Faury D, Fleming A, Zakrzewska M, Liberski PP Zakrzewski K, Hauser P, Garami M, Klekner A, Bognar L, Morrissy S, Cavalli F, Taylor MD, van Sluis P, Koster J, Versteeg R, Volckmann R, Mikkelsen T, Aldape K, Reifenberger G, Collins VP, Majewski J, Korshunov A, Lichter P, Plass C, Jabado N, Pfister SM (2012) Hotspot mutations in H3F3A and IDH1 define distinct epigenetic and biological subgroups of glioblastoma. Cancer Cell 22(4): 425-437.

Tomlinson FH, Scheithauer BW, Hayostek CJ, Parisi JE, Meyer FB, Shaw EG, Weiland TL, Katzmann JA, Jack Jr. CR (1994) The significance of atypia and histologic malignancy in pilocytic astrocytoma of the cerebellum: a clinicopathologic and flow cytometric study. J Child Neurol 9(3): 301-310.

Wolff B, Ng A, Roth D, Parthey K, Warmuth-Metz M, Eyrich M, Kordes U, Kortmann R, Pietsch T, Kramm C, Wolff JE (2012) Pediatric high grade glioma of the spinal cord: results of the HIT-GBM database. J Neurooncol 107(1): 139-146.
Wolff JE, Driever PH, Erdlenbruch B, Kortmann RD, Rutkowski S, Pietsch T, Parker C, Metz MW, Gnekow A, Kramm CM (2010a) Intensive chemotherapy improves survival in pediatric high-grade glioma after gross total resection: results of the HIT-GBM-C protocol. Cancer 116(3): 705-712.

Wolff JE, Kortmann RD, Wolff B, Pietsch T, Peters O, Schmid HJ, Rutkowski S, Warmuth-Metz M, Kramm C (2010b) High dose methotrexate for pediatric high grade glioma: results of the HIT-GBM-D Pilot study. J Neurooncol 102(3): 433-442.

Wolff JE, Kortmann RD, Wolff B, Pietsch T, Peters O, Schmid HJ, Rutkowski S, Warmuth-Metz M, Kramm C (2011) High dose methotrexate for pediatric high grade glioma: results of the HIT-GBM-D pilot study. J Neurooncol 102(3): 433-442.

Wolff JE, Molenkamp G, Westphal S, Pietsch T, Gnekow A, Kortmann RD, Kuehl J (2000) Oral trofosfamide and etoposide in pediatric patients with glioblastoma multiforme. Cancer 89(10): 2131-2137.

Wolff JE, Wagner S, Reinert C, Gnekow A, Kortmann RD, Kuhl J, Van Gool SW (2006) Maintenance treatment with interferon-gamma and low-dose cyclophosphamide for pediatric high-grade glioma. J Neurooncol 79(3): 315-321.

This work is published under the standard license to publish agreement. After 12 months the work will become freely available and the license terms will switch to a Creative Commons AttributionNonCommercial-Share Alike 3.0 Unported License. 